\title{
Mechanizm rozliczenia podatku od towarów i usług $w$ relacji inwestor - główny wykonawca (nabywca usług budowlanych) oraz wykonawca w kontekście zmian prawnych obowiązujących od 1 stycznia 2017 r.
}

The mechanism of settling tax on goods and services in the relationship between the investor - main contractor (buyer of construction services) and another contractor in the light of legal changes in force from January 1, 2017

Streszczenie. Opracowanie poświęcone zostało omówieniu funkcji obowiązującego od 1 stycznia 2017 r. mechanizmu tzw. odwróconego obciążenia w zakresie robót budowlanych na przykładzie modelu, w którym inwestor wykonuje samodzielnie część robót, a pozostałą część zleca do wykonania innym podmiotom. 
Opracowanie stanowi jednocześnie próbę ustalenia, czy na podstawie dostępnych danych można określić, że rozszerzenie zastosowania przepisów w zakresie mechanizmu odwróconego obciążenia przyczyniło się do poprawy ściągalności podatku od towarów i usług.

Słowa kluczowe: podatek VAT; odwrotne obciążenie; roboty budowlane.

Abstract. The study is devoted to the examination of the function of the so called reverse charge mechanism in the field of construction works. This mechanism is in force from Jan 1, 2017. The analysis is based on the example of a model in which the contractor performs part of the works on his/her own, and s/he commissions the remaining part of the works to other entities. The study is also an attempt to establish whether it is possible to determine on the grounds of available data that an extension of the application of the regulations of reverse burden mechanism contributed to the improvement of tax collection.

Keywords: VAT; reverse charge; construction works.

\section{Wstęp}

Wybór tematu został podyktowany wątpliwościami interpretacyjnymi związanymi z zakresem zastosowania mechanizmu odwróconego obciążenia obowiązującego od 1 stycznia 2017 r. ${ }^{1}$ przez osoby prawne, jednostki organizacyjne niemające osobowości prawnej oraz osoby fizyczne nabywające usługi wymienione w załączniku nr 14 (poz. 2-48) do ustawy o podatku od towarów i usług ${ }^{2}$ w relacji inwestor - główny wykonawca (nabywca usług budowlanych) oraz wykonawca.

Problem związany z wyborem sposobu rozliczenia pomiędzy podatnikami w przedstawionej konfiguracji nie stanowi wyłącznie zagadnienia akademickiego z zakresu teorii prawa podatkowego, a dotyczy całej grupy podmiotów, które świadcząc usługi budowlane, zasadniczo stają przed dylematem związanym z prawidłowym wyborem pomiędzy zastosowa-

\footnotetext{
$1 \quad$ Art. 1 pkt 1 lit. a ustawy z dnia 1 grudnia 2016 r. o zmianie ustawy o podatku od towarów i usług oraz niektórych innych ustaw (Dz.U. z 2016 r., poz. 2024).

2 Ustawa z dnia 11 marca 2004 r. o podatku od towarów i usług (tekst jedn. Dz.U. z 2017 r., poz. 1221), dalej: ustawa o VAT.
} 
niem ogólnych zasad opodatkowania a mechanizmem odwróconego obciążenia.

Celem opracowania jest omówienie funkcji mechanizmu tzw. odwróconego obciążenia w zakresie robót budowlanych obowiązującego od 1 stycznia 2017 r. na przykładzie modelu, w którym inwestor wykonuje samodzielnie część robót, a pozostałą część zleca do wykonania innym podmiotom. Ponadto opracowanie stanowi próbę ustalenia, czy na podstawie dostępnych danych można określić, że rozszerzenie zastosowania przepisów w zakresie mechanizmu odwróconego obciążenia, stanowiące część reformy systemu podatkowego ${ }^{3}$, przyczyniło się do poprawy ściągalności podatku od towarów i usług. W tym miejscu wyłącznie informacyjnie należy zaznaczyć, że wprowadzenie mechanizmu odwróconego obciążenia w zakresie usług wymienionych w załączniku nr 14 (poz. 248) do ustawy o VAT stanowi część reformy systemu podatkowego ukierunkowanej na poprawę ściągalności podatków oraz funkcjonowania aparatu skarbowego, a w konsekwencji na zwiększenie wpływów budżetowych bez konieczności podwyższania dotychczasowych stawek podatkowych. Reforma ta w szerszym kontekście objęła poza procedurą podatkową, prawem materialnym podatkowym oraz ustrojowym również zaostrzenie sankcji karnych oraz karnoskarbowych za przestępstwa związane z wyłudzeniem podatku od towarów i usług 4 .

3 Polegającej m.in. na wprowadzeniu mechanizmu Jednolitego Pliku Kontrolnego (JPK), mechanizmu podzielonej płatności, tzw. split payment, mechanizmu odwróconego obciążenia na materiały budowlane oraz klauzuli przeciwko unikaniu opodatkowania (szerzej P. Borszowski, Klauzula przeciwko unikaniu opodatkowania. Praktyczne vademecum podatnika - 2017, Wrocław 2017). Celem wprowadzenia klauzuli przeciwko unikaniu opodatkowania (ang. general anti-avoidance rule - GAAR) jest zwalczanie sztucznych czynności (lub ich zespołów), zwykle zawierających elementy zagraniczne, wykorzystywanych zazwyczaj przez wielkie korporacje do unikania zapłaty podatku, zob. założenia projektu budżetu państwa na rok 2017, Warszawa, czerwiec 2016 r., s. 14, http://www.mf.gov.pl/documents/764034/5682771/20160609_zalozenia_UB2017_090620 16.pdf, (dostęp: 30.05 .2018 r.).

4 Metody wyłudzenia podatku od towarów i usług należy zasadniczo podzielić na dwa rodzaje: dotyczące podatku należnego oraz dotyczące podatku naliczonego i zwrotu podatku. Zob. projekt ustawy o zmianie ustawy - Kodeks karny oraz niektórych innych ustaw, Sejm RP VIII kadencji, druk sejmowy nr 888, s. 7. 


\section{Geneza przepisów dotyczących odwróconego obciążenia}

Przed ustaleniem sposobu rozliczenia podatku od towarów i usług we wskazanym modelu badawczym należy poczynić kilka uwag o charakterze ogólnym w zakresie specyfiki mechanizmu odwróconego obciążenia, sięgając również do jego rodowodu historycznego w polskim systemie prawnym.

Istota mechanizmu odwrotnego obciążenia sprowadza się do tego, że obowiązek zapłaty podatku należnego z tytułu danej transakcji ciąży na nabywcy danych towarów i usług, który jest uprawniony do odliczenia podatku naliczonego. W odróżnieniu od ogólnych zasad opodatkowania w tym przypadku bowiem sprzedawca nie rozlicza podatku, w następstwie czego nie wystąpi przepływ podatku pomiędzy kontrahentami, co w konsekwencji eliminuje możliwość nadużycia konstrukcji podatku, a to dlatego, że cena, jaką obowiązany jest zapłacić nabywca, to cena netto. Opodatkowana na zasadach ogólnych jest natomiast transakcja zawierana z ostatecznym konsumentem, który płaci podatek sprzedawcy ${ }^{5}$.

Punktem wyjścia do dalszych rozważań dotyczących wprowadzenia do ustawy o VAT regulacji w zakresie odwróconego obciążenia powinny być przepisy dyrektywy Rady 2006/112/WE z dnia 28 listopada 2006 r. w sprawie wspólnego systemu podatku od wartości dodanej ${ }^{6}$. Dyrektywa 112 w art. 199 przewiduje opcjonalną możliwość zobowiązania do zapłaty podatku od towarów i usług odbiorców wymienianych w tym przepisie towarów i usług. Omawiane przepisy zostały wprowadzone po raz pierwszy dyrektywą Rady 2006/69/WE z dnia 24 lipca 2006 r. zmieniającą dyrektywę 77/388/EWG w odniesieniu do niektórych środków w celu uproszczenia procedury obciążenia podatkiem od wartości dodanej i pomocy w zwalczeniu uchylania się od opodatkowania lub unikania opodat-

5 J. Szlęzak-Matusewicz, Odwrotne obciq̨żenie podatkiem od towarów i usług jako mechanizm przeciwdziałajqcy oszustwom podatkowym, „Zeszyty Naukowe Uniwersytetu Szczecińskiego nr 864, Finanse, Rynki Finansowe, Ubezpieczenia” 2015, nr 76, t. 1, s. 269, 271, http://www.wneiz.pl/nauka_wneiz/frfu/76-2015/FRFU-76-t1-265.pdf (dostęp: 17.09.2018 r.).

6 Dz.Urz. UE L 347 z dnia 11 grudnia 2006, s. 1, dalej: dyrektywa 112. 
kowania oraz uchylającej niektóre decyzje przyznające odstępstwa ${ }^{7}$ w tekście szóstej dyrektywy Rady 77/388/EWG z dnia 17 maja 1977 r. w sprawie harmonizacji ustawodawstw państw członkowskich w odniesieniu do podatków obrotowych - wspólny system podatku od wartości dodanej ${ }^{8}$.

Z omawianej regulacji wynika, że wprowadzenie mechanizmu odwróconego obciążenia przez państwa członkowskie UE nie jest obowiązkowe. Dyrektywa zezwala na ograniczenie zastosowania tego mechanizmu wyłącznie do określonych dostaw towarów i świadczenia usług. Państwa mogą również określić kategorie dostaw, usługodawców, nabywców lub usługobiorców, do których mogą mieć zastosowanie środki określone w art. 199 dyrektywy 112, a na podstawie ust. 2 omawianego przepisu państwa członkowskie zasadniczo mogą dowolnie ograniczać zakres przedmiotowy i podmiotowy stosowania omawianego mechanizmu w zakresie określonym przepisami dyrektywy ${ }^{9}$.

Z kolei na podstawie art. 199a dyrektywy 112 państwa członkowskie mogą do dnia 31 grudnia 2018 r. i na okres co najmniej dwóch lat postanowić, że osobą zobowiązaną do zapłaty podatku od towarów i usług jest podatnik, na rzecz którego wykonywana jest dowolna usługa lub dostarczany dowolny towar spośród wymienionych w omawianym przepisie. Ponadto państwo członkowskie może wyznaczyć odbiorcę jako osobę zobowiązaną do zapłaty podatku od towarów i usług z tytułu określonego rodzaju dostawy towarów i świadczenia usług w drodze odstępstwa od art. 193 w przypadkach oraz na warunkach określonych w art. $199 \mathrm{~b}^{10}$.

7 Dz.Urz. UE L 221 z dnia 12 sierpnia 2006, s. 9.

8 Dz.Urz. UE L 145 z dnia 13 czerwca 1977, r. s. 1. Zob. D. Dominik-Ogińska, D. Polakowski, Mechanizm odwróconego obciq̨żenia podatkiem od towarów i usług na usługi budowlane. Praktyczne vademecum podatnika, Wrocław 2017, s. 13.

$9 \quad$ Wyrok WSA w Bydgoszczy z dnia 20 lutego 2013 r., I SA/Bd 3/13, Lex nr 1350764 oraz wyrok WSA w Bydgoszczy z dnia 24 marca 2015 r., I SA/Bd 602/14, Lex nr 1850469.

10 Państwo członkowskie przekazuje Komisji informacje wskazujące sektor, którego dotyczy problem oszustw, rodzaj i cechy oszustwa, uzasadnienie szczególnie pilnej potrzeby, nagły i znaczący charakter oszustwa oraz jego skutki w postaci znacznych i nieodwracalnych strat finansowych, na podstawie których, w przypadku braku sprzeciwu, Komisja przekazuje zainteresowanemu państwu członkowskiemu i Komitetowi ds. VAT pisemne potwierdzenie. Dopiero wtedy to państwo członkowskie może przy- 
W Polsce wprowadzenie i rozszerzenie katalogu czynności dokonanych na terytorium kraju, które zostały objęte mechanizmem odwróconego obciążenia, nastąpiło w latach 2011-2017. Nowelizacją z dnia 18 marca 2011 r. do art. 17 ustawy o VAT został dodany ust. 1 pkt 7 i 8 w zakresie opodatkowania dostaw złomu oraz świadczenia usług w zakresie przenoszenia uprawnień do emisji do powietrza gazów cieplarnianych ${ }^{11}$. Następnie ustawodawca nowelizacją z dnia 9 czerwca 2011 r. zdecydował się na objęcie odwróconym obciążeniem dostaw towarów wymienionych w załączniku nr 11 do ustawy o VAT, m.in. dostawy odpadów i złomu metali nieszlachetnych, odpadów szklanych, odpadów gumowych oraz odpadów tworzyw sztucznych ${ }^{12}$. Przepisy kolejnej nowelizacji w zakresie stosowania mechanizmu odwróconego obciążenia objęły przede wszystkim dostawę wyrobów stalowych, takich jak m.in. pręty stalowe i kształtniki stalowe, wyroby z miedzi i innych stopów ${ }^{13}$. Od 1 lipca 2015 r. katalog towarów wymienionych w załączniku nr 11 do ustawy o VAT uległ rozszerzeniu o kolejne towary z grupy wyrobów stalowych, złota, metali nieżelaznych oraz z kategorii elektroniki (komputery przenośne, telefony komórkowe, konsole do gier wideo) $)^{14}$. Ostatecznie od dnia 1 stycznia 2017 r. katalog towarów wymienionych w załączniku nr 11 do ustawy o VAT uległ dalszemu rozszerzeniu o towary z grupy wyrobów ze srebra, złota i platyny oraz z kategorii elektroniki (procesory), a co najistotniejsze z punktu widzenia przedmiotowego opracowania, odwróconym obciąże-

jąć szczególny środek w ramach mechanizmu szybkiego reagowania od dnia otrzymania potwierdzenia.

11 Art. 1 ust. 7 ustawy z dnia 18 marca 2011 r. o zmianie ustawy o podatku od towarów i usług oraz ustawy - Prawo o miarach (Dz.U. z 2011 r. Nr 64, poz. 332).

12 Art. 1 ust. 7 lit. a tiret 2 ustawy z dnia 9 czerwca 2011 r. o zmianie ustawy o podatku od towarów i usług, ustawy o zasadach ewidencji i identyfikacji podatników i płatników oraz ustawy o transporcie drogowym (Dz.U. z 2011 r. Nr 134, poz. 780).

13 Art. 1 pkt 7 ustawy z dnia 26 lipca 2013 r. o zmianie ustawy o podatku od towarów i usług oraz niektórych innych ustaw (Dz.U. z 2013 r. poz. 1027).

14 Art. 1 pkt 19 lit. d ustawy z dnia 9 kwietnia 2015 r. o zmianie ustawy o podatku od towarów i usług oraz ustawy - Prawo zamówień publicznych (Dz.U. z 2015 r. poz. 605). 
niem zostały objęte usługi budowlane wymienione w załączniku nr 14 do ustawy o $\mathrm{VAT}^{15}$.

\section{Cel znowelizowanych przepisów rozszerzających stosowanie mechanizmu odwróconego obciążenia}

Omawiana nowelizacja z dnia 1 grudnia 2016 r. rozszerzyła również zastosowanie mechanizmu odwróconego obciążenia na niektóre transakcje mające za przedmiot świadczenie usług budowlanych, usług w zakresie przenoszenia uprawnień do emisji gazów cieplarnianych - bez względu na symbol PKWiU - oraz roboty budowlane, ogólnobudowlane i peryferyjne w stosunku do poprzednio wymienionych w pozycjach od 2 do 48. Ustawodawca wprowadził omawiane zmiany w celu przeciwdziałania nieprawidłowościom zaobserwowanym na rynku tych właśnie usług, w szczególności związanych z problemem oszustw ${ }^{16}$ w zakresie podatku od towarów i usług ${ }^{17}$.

15 Ustawa z dnia 1 grudnia 2016 r. o zmianie ustawy o podatku od towarów i usług oraz niektórych innych ustaw (Dz.U. z 2016 r. poz. 2024). Zob. zestawienie Odwrotne obciqż̇enie 2017 - usługi budowlane i towary, „Poradnik Gazety Prawnej” 2017, nr 2 (888), s. 5.

16 Tj. przypadkom uchylania się od zapłaty podatku przez usługodawców, którzy dysponowali kwotą podatku od towarów i usług zawartą w fakturze, zob. J. Fornalik tyt. XI, art. 193-212 [w:] K. Sachs, R. Namysłowski (red.), Dyrektywa VAT, Warszawa 2008, s. 874. Z oszustwem podatkowym sensu stricto mamy do czynienia w przypadku zachowania inkryminowanego w art. 56 § 1 ustawy z dnia 10 września 1999 r. - Kodeks karny skarbowy (Tekst jedn. Dz.U. z 2017 r., poz. 2226, dalej: k.k.s.) w różnych jego odmianach. W art. $56 \S 1$ k.k.s. zawarte są dwa przedmioty ochrony: prawidłowość działania organów administracji oraz mienie Skarbu Państwa lub innego uprawnionego podmiotu, które zostaje narażone na uszczuplenie. Mienie to jest związane ze świadczeniami podatkowymi. Są to kwoty pieniężne, do których uzyskania uprawniony jest organ podatkowy lub inny właściwy organ z tytułu obowiązku uiszczania podatków (wyrok NSA z dnia 17 maja 2017 r., II GSK 2461/15, Lex nr 2336562). W piśmiennictwie podobnie jak w orzecznictwie podkreśla się różnicę pomiędzy uchylaniem się od opodatkowania a nadużyciem mechanizmów podatkowych. W pierwszym przypadku sprawa dąży do minimalizacji obciążeń podatkowych, w konsekwencji czego Skarb Państwa otrzymuje mniejsze przychody z tytułu podatków, niż powinien, natomiast $\mathrm{w}$ drugim przypadku mamy do czynienia z instrumentalnym wykorzystaniem mechanizmów podatkowych w celu uzyskania bezpodstawnych przysporzeń kosztem Skarbu 
Celem zmian legislacyjnych związanych z rozszerzeniem zakresu stosowania tzw. mechanizmu odwróconego obciążenia o transakcje, których przedmiotem są usługi wymienione w załączniku nr 14 do ustawy, jest zapewnienie większej skuteczności i uszczelnienia przepisów dotyczących podatku od towarów i usług za pomocą mechanizmu odwróconego obciążenia $^{18}$. Wprowadzone przez ustawodawcę zmiany legislacyjne zostały przede wszystkim ukierunkowane na poprawę ściągalności tego podatku $^{19}$, m.in. poprzez redukcję skali oszustw i nadużyć ${ }^{20}$, a także na usprawnienie już istniejących instrumentów ich zwalczania ${ }^{21}$.

Obecnie mechanizm odwróconego obciążenia w uregulowaniu krajowym uległ rozszerzeniu na branże najbardziej newralgiczne z punktu widzenia nadużycia prawa do odliczenia podatku. Mechanizm ten rozszerzony został z transakcji transgranicznych na świadczenie usług dokonywanych w obrocie krajowym w celu przerwania, a co najmniej ogranicze-

Państwa, zob. J. Duży, Zorganizowana przestępczość podatkowa w Polsce. Zwalczanie przestępnego nadużycia mechanizmów podatków VAT i akcyzowego, Warszawa 2013, s. 29.

Rządowy projekt ustawy o zmianie ustawy o podatku od towarów i usług oraz niektórych innych ustaw, Sejm RP VIII kadencji, druk sejmowy nr 965, s. 34, http://www.sejm.gov.pl/sejm8.nsf/agent.xsp?symbol=RPL\&Id=RM-10-123-16 (dostęp: 28.10.2016 r.). Tamze.

19 Objaśnienia podatkowe z 17 marca 2017 r. Stosowanie mechanizmu odwróconego obciq̨żenia $w$ transakcjach dotyczqcych świadczenia usług budowlanych, s. 1, http://www.finanse.mf.gov.pl/documents/766655/1402295/Obja\%C5\%9Bnienia+podat kowe+z+17+marca+2017+r..pdf (dostęp: 17.03.2017 r.).

20 Przywołując dorobek orzecznictwa, należy wskazać, że prawnokarna ocena nadużyć procedury obliczania i uiszczania podatku od towarów i usług może zostać sprowadzona do dwóch zasadniczych zagadnień. Jeżeli wystawca „fikcyjnej” faktury VAT, niedokumentującej rzeczywistego zdarzenia gospodarczego, lub osoba posługująca się taką fakturą godzi swoim zachowaniem w obowiązki podatkowe, to sprawca takiego czynu odpowiada za występek inkryminowany w art. $62 \S 2$ k.k.s. Natomiast gdy sprawca zmierza do wyłudzenia nienależnego zwrotu podatku od towarów i usług, to popełnia przestępstwo skarbowe z art. 76 § 1 k.k.s. Jednakże w wypadku, gdy „fikcyjną” fakturę VAT wystawiono wyłącznie dla przestępczych celów pozapodatkowych, np. w celu wyłudzenia kredytu lub dotacji, to wystawca takiej faktury lub osoba posługująca się nią powinni odpowiadać na podstawie przepisów ustawy karnej innej niż k.k.s., np. z art. 297 k.k. lub z art. $286 \S 1$ k.k. (wyrok SA we Wrocławiu z dnia 3 września 2009 r., II AKa 105/09, Lex nr 519593).

Rządowy projekt ustawy..., s. 31. 
nia procederu związanego z wyłudzeniem podatku od towarów i usług przez podmioty, które w rzeczywistości nie świadczą usług, a jedynie ewidencjonują nieistniejące (fikcyjne) zdarzenia gospodarcze. Wprowadzenie omawianego mechanizmu skutkuje tym, że nie dochodzi do konieczności zapłaty podatku przez nabywcę usług, co w konsekwencji wyklucza możliwość uzyskania nienależnego zwrotu podatku od towarów i usług z budżetu państwa ${ }^{22}$.

Działania normatywne ustawodawcy krajowego odpowiadają celom ustawodawcy unijnego określonym w dyrektywie 112, która w art. 199 umożliwia państwom członkowskim przerzucenie obowiązku rozliczenia podatku od towarów i usług na nabywcę. Pierwszym z omawianych celów niezaprzeczalnie było uproszczenie zasad rozliczania transakcji pomiędzy podmiotami opodatkowanymi. Pragmatyzm przyjętego rozwiązania wyraża się w tym, że nabywca może jednocześnie dokonać rozliczenia podatku naliczonego z należnym. Drugi, nie mniej ważny cel to umożliwienie wprowadzenia krajom członkowskim mechanizmu powodującego skuteczniejsze egzekwowanie należności w odniesieniu do pewnych kategorii transakcji, a w konsekwencji przeciwdziałanie zjawisku unikania opodatkowania oraz uchylania się przed opodatkowaniem ${ }^{23}$.

W literaturze wskazuje się, że podstawową i zasadniczą przyczyną aktywności legislacyjnej związanej z rozszerzeniem zastosowania mechanizmu odwróconego obciążenia jest coroczna utrata wpływów do budżetu z tytułu podatków, w szczególności podatku od towarów i usług. Problem utraty wpływów jest związany jednocześnie z pokrzywdzeniem podmiotów z branż newralgicznych, najbardziej narażonych na nieuczciwą działalność podmiotów dopuszczających się wyłudzeń podatków ${ }^{24}$. Nie powinien zatem zaskakiwać kierunek zmian legislacyjnych, w tym zmian w zakresie prawa karnego skarbowego oraz prawa karnego powszechnego.

22 M. Majczyna, Odwrotne obciqżenie a oszustwa w VAT, [w:] I. Ożóg (red.), Przestępstwa karuzelowe i inne oszustwa w VAT, Warszawa 2017, s. 329.

23 M. Wojda, [w:] J. Martini (red.), Dyrektywa VAT 2006/112/WE, Wrocław 2010, s. 865.

24 M. Majczyna, Odwrotne obciq̨żenie..., s. 329. 


\section{Zakres podmiotowy zastosowania przepisów dotyczących mechanizmu odwróconego obciążenia do niektórych usług związanych z rynkiem budowlanym}

Zgodnie z obowiązującym brzmieniem art. 17 ust. 1 pkt 8 ustawy o podatku od towarów i usług - podatnikami są również osoby prawne, jednostki organizacyjne niemające osobowości prawnej oraz osoby fizyczne nabywające usługi wymienione w załączniku nr 14 do ustawy, jeżeli łącznie spełnione są następujące warunki:

- usługodawcą jest podatnik, o którym mowa w art. 15, u którego sprzedaż nie jest zwolniona od podatku na podstawie art. 113 ust. 1 i 9;

- usługobiorcą jest podatnik, o którym mowa w art. 15, zarejestrowany jako podatnik VAT czynny.

Z powyższego uregulowania wynika, że ustawodawca podobnie wprowadził ograniczenie stosowania mechanizmu odwróconego obciążenia podatkiem VAT do przypadków, w których usługobiorca jest podatnikiem VAT czynnym ${ }^{25}$. Ponadto mechanizm odwróconego obciążenia określony w przepisie art. 17 ust. 1 pkt 8 ustawy o VAT w przypadku usług wymienionych w poz. 2-48 załącznika nr 14 do ustawy stosuje się, jeżeli usługodawca świadczy te usługi jako podwykonawca.

Z przytoczonego uregulowania wynikają dwie istotne informacje: po pierwsze, iż warunkiem zastosowania mechanizmu odwróconego obciążenia w stosunku do nabywców usług wymienionych w poz. 2-48 załącznika nr 14 do ustawy o VAT jest zawarcie transakcji pomiędzy podatnikami VAT czynnymi, a po drugie, że usługi te musi świadczyć podwykonawca ${ }^{26}$.

25 Zastosowanie takiego rozwiązania, a więc wykorzystanie odwróconego obciążenia wyłącznie w sytuacji, gdy dostawca towarów/usługodawca oraz nabywca towarów/usługobiorca są podatnikami VAT czynnymi, nie ogranicza skuteczności tego mechanizmu. Tamże.

26 Definicja i status podwykonawcy, a także innych uczestników procesu budowlanego zostały szczegółowo omówione w kolejnej części opracowania przy okazji określenia sposobu rozliczenia w relacji główny wykonawca (nabywca usług budowlanych) wykonawca. 
Ustawodawca w art. 15 ust. 1 ustawy o VAT formułuje ogólną definicję podatnika, wskazując, że podatnikami są osoby prawne, jednostki organizacyjne niemające osobowości prawnej oraz osoby fizyczne, wykonujące samodzielnie działalność gospodarczą bez względu na cel lub rezultat takiej działalności ${ }^{27}$. Podatnicy podatku zgodnie z dyspozycją art. 96 ust. 1 ustawy o VAT są obowiązani przed dniem wykonania pierwszej czynności opodatkowanej, z zastrzeżeniem wyjątków przewidzianych ustawą, złożyć naczelnikowi urzędu skarbowego zgłoszenie rejestracyjne. Istotny z punktu widzenia kierunku obecnej interpretacji prawa do odliczenia aprobowanej przez TSUE $^{28}$ jest pogląd, zgodnie z którym status danego podmiotu jako podatnika VAT jest niezależny od faktu rejestracji $^{29}$. Obecnie, zgodnie ze znowelizowanym art. 17 ust. 1 pkt 7 ustawy o VAT, już nie tylko sprzedawca, ale i nabywca ma być czynnym podatnikiem, a weryfikacja tego stanu spoczywa na sprzedawcy, ponieważ to on jest odpowiedzialny za poprawne opodatkowanie transakcji ${ }^{30}$.

Istotny z punktu widzenia omawianej nowelizacji jest również drugi warunek, tj. posiadanie przez usługodawcę statusu podwykonawcy. Termin podwykonawca nie został zdefiniowany przez ustawodawcę podatkowego ani kodeksowego, co w konsekwencji uniemożliwia ustalenie

27 Działalność gospodarcza to prawnie określona sytuacja, którą trzeba oceniać na podstawie zbadania konkretnych okoliczności faktycznych wypełniających znamiona tej działalności lub ich niewypełniających. Prowadzenie działalności gospodarczej jest zatem kategorią obiektywną, niezależnie od tego, jak działalność tę ocenia sam prowadzący ją podmiot i jak ją nazywa oraz czy dopełnia ciążących na nim obowiązków z tą działalnością związanych, czy też nie. Zob. wyrok WSA w Szczecinie z dnia 24 maja 2017 r., I SA/Sz 320/17, Lex nr 2314835.

28 Trybunał Sprawiedliwości Unii Europejskiej.

29 Z samej rejestracji nie można wywodzić prawa do odliczenia podatku naliczonego. Status danego podatnika jako podatnika VAT jest kategorią obiektywną, niezależną od woli osoby dokonującej zgłoszenia rejestracyjnego lub od stanowiska organów podatkowych. Co do zasady rejestracja podatnika VAT nie kreuje statusu podatkowego, a tylko warunkuje możliwość skorzystania z prawa do odliczenia, gdy osoba dokonująca zgłoszenia jest obiektywnie podatnikiem podatku VAT. Oznacza to, że art. 96 ust. 1 ustawy o VAT jest jedynie dopełnieniem regulacji zawartej w art. 15 ust. 1 tej ustawy; analogiczną rolę pełni art. 96 ust. 2 ustawy o VAT w stosunku do regulacji zawartej w art. 15 ust. 4 (wyrok WSA w Poznaniu z dnia 22 czerwca 2017 r., I SA/Po 19/17, Lex nr 231293).

30 J. Szlęzak-Matusewicz, Odwrotne obciqżenie..., s. 271. 
zakresu znaczeniowego tego terminu na podstawie definicji zawartych w podatkowych oraz w pozapodatkowych aktach normatywnych, a co za tym idzie - powoduje konieczność ustalenia tego zakresu poprzez zastosowanie wykładni prawa. Ustalając zakres danego pojęcia, wskazać należy, że w procesie wykładni prawa przyjmuje się domniemanie posłużenia się przez ustawodawcę językiem powszechnym ${ }^{31}$.

Definicja słownikowa określa podwykonawcę jako osobę lub firmę, która wykonuje jakieś prace dla innego, głównego wykonawcy określonego przedsięwzięcia $^{32}$. Na potoczne znaczenie tego terminu wskazuje również ustawodawca podatkowy ${ }^{33}$. W tym miejscu należy się zastanowić, jakie znaczenie dla ustalenia znaczenia terminu nieposiadającego definicji legalnej w ustawie podatkowej ma fakt użycia tego terminu na gruncie innych gałęzi prawa. Zatem pomocniczo osiągnięty rezultat wykładni można porównać z kontekstem znaczeniowym użytym w innych uregulowaniach. W art. $647^{1}$ i $649^{5}$ k.c. omawianym terminem posłużono się na określenie podmiotu, który świadczy usługi w ramach umowy o roboty na rzecz wykonawcy ${ }^{34}$.

Również ustawa z dnia 7 lipca 1994 r. - Prawo budowlane nie definiuje terminu podwykonawcy ${ }^{35}$. Natomiast przepis art. 17 u.p.b. wymienia następujących uczestników procesu budowlanego: inwestor, inspektor nadzoru inwestorskiego, projektant, kierownik budowy lub kierownik robót. Wykonawca (dalszy wykonawca czy też podwykonawca) nie jest więc uczestnikiem procesu budowlanego w rozumieniu prawa budowlanego. A więc spośród podmiotów wymienionych w tytule XVI kodeksu, zatytułowanym „Umowa o roboty budowlane”, tj. inwestora, wykonawcy i pod-

\footnotetext{
31 B. Brzeziński, Szkice z wykładni prawa podatkowego, Gdańsk 2002, s. 35.

32 http://wsjp.pl/index.php?id_hasla=52661\&ind=0\&w_szukaj=podwykonawca; (dostęp: 31.10.2018 r.).

33 Objaśnienia podatkowe z 17 marca 2017 r. ..., s. 5.

34 Zgodnie z art. $647^{1} \S 1$ k.c. inwestor odpowiada solidarnie z wykonawcą (generalnym wykonawcą) za zapłatę wynagrodzenia należnego podwykonawcy z tytułu wykonanych przez niego robót budowlanych, których szczegółowy przedmiot został zgłoszony inwestorowi przez wykonawcę lub podwykonawcę przed przystąpieniem do wykonywania tych robót, chyba że w ciągu trzydziestu dni od dnia doręczenia inwestorowi zgłoszenia inwestor złożył podwykonawcy i wykonawcy sprzeciw wobec wykonywania tych robót przez podwykonawcę.

35 Tekst jedn. Dz.U. z 2017 r. poz. 1332, dalej: u.p.b.
} 
wykonawcy, tylko inwestor, jako uczestnik procesu budowlanego w rozumieniu prawa budowlanego, jest koniecznym podmiotem $w$ tym procesie ${ }^{36}$.

Należy również zwrócić uwagę na definicję normatywną zawartą w art. 2 ust. 9b ustawy z dnia 29 stycznia 2004 r. - Prawo zamówień publicznych $^{37}$. Zgodnie $\mathrm{z}$ tym uregulowaniem przez umowę o podwykonawstwo należy rozumieć umowę w formie pisemnej o charakterze odpłatnym, której przedmiotem są usługi, dostawy lub roboty budowlane stanowiące część zamówienia publicznego, zawartą między wybranym przez zamawiającego wykonawcą a innym podmiotem (podwykonawcą), a w przypadku zamówień publicznych na roboty budowlane także między podwykonawcą a dalszym podwykonawcą lub między dalszymi podwykonawcami. Pojęcie podwykonawcy nie zostało zdefiniowane również i w tej ustawie, niemniej jednak z definicji legalnej umowy o podwykonawstwo można wyprowadzić wniosek, że podwykonawcą będzie dalszy wykonawca w stosunku do wykonawcy wyłonionego przez zamawiającego ${ }^{38}$.

\section{Zastosowanie mechanizmu odwróconego obciążenia na przykładzie rozliczenia pomiędzy inwestorem - wykonawcą (nabywcą usług budowlanych) oraz wykonawcą}

Wprowadzana nowelizacja w zakresie mechanizmu odwróconego obciążenia spowodowała powstanie wątpliwości w zakresie wyboru sposobu opodatkowania transakcji inwestor - główny wykonawca (nabywca usług budowlanych) oraz wykonawca. We wskazanym modelu zamiarem wy-

36 Bez powzięcia przez inwestora zamiaru realizacji określonej inwestycji budowlanej nie ma mowy o działalności budowlanej w zakresie określonej inwestycji budowlanej. A. Plucińska-Filipowicz, M. Wierzbowski (red.), Prawo budowlane. Komentarz aktualizowany, Warszawa 2016, s. 18.

37 Tekst jedn. Dz.U. z 2015 r., poz. 2164.

38 O charakterze wtórnym podwykonawcy w stosunku do wykonawcy wybranego przez zamawiającego po przeprowadzeniu procedury udzielenia zamówienia publicznego świadczą inne postanowienia ustawy Prawo zamówień publicznych, chociażby art. 36b ust. u.p.z.p., zgodnie z którym zamawiający żąda wskazania przez wykonawcę części zamówienia, których wykonanie zamierza powierzyć podwykonawcom, i podania przez wykonawcę firm podwykonawców. 
konawcy, będącego czynnym podatnikiem VAT, jest świadczenie części spośród usług wymienionych w załączniku nr 14 (poz. 2-48) do ustawy o VAT na rzecz innego czynnego podatnika, prowadzącego działalność gospodarczą polegającą na budowaniu i sprzedaży nieruchomości, w szczególności lokali mieszkalnych. Modus operandi tego ostatniego przedsiębiorcy polega na nabywaniu gruntu pod inwestycję, dostarczeniu projektu budowlanego, organizacji i uczestnictwie w wykonaniu obiektu budowlanego, zawieraniu umów sprzedaży nieruchomości, w tym umów deweloperskich, oraz zbywaniu nieruchomości. Funkcje te zasadniczo odpowiadają obowiązkom zarówno inwestora, który zgodnie z art. 647 k.c. zobowiązany jest do dokonania wymaganych przez właściwe przepisy czynności związanych z przygotowaniem robót, w szczególności do przekazania terenu budowy i dostarczenia projektu, jak i wykonawcy, który w myśl dyspozycji tego samego przepisu zobowiązany jest do oddania przewidzianego $\mathrm{w}$ umowie obiektu, wykonanego zgodnie $\mathrm{z}$ projektem i z zasadami wiedzy technicznej.

Uregulowanie kodeksowe rozdziela obie funkcje w celu umożliwienia zawarcia umowy pomiędzy dwoma niezależnymi od siebie podmiotami, tj. inwestorem i wykonawcą. Natomiast w omawianym modelu część robót budowlanych ${ }^{39}$ będzie wykonywana przez samego inwestora, natomiast wykonanie części z nich zostanie powierzone innym przedsiębiorcom. W konsekwencji w umowach o roboty budowlane wykonywanych na rzecz inwestora oraz w dzienniku budowy inwestor nazywany jest odpowiednio głównym wykonawcą lub wykonawcą, a kolejny przedsiębiorca nazywany jest podwykonawcą. Podkreślenia wymaga fakt, że inwestor ma zamiar powierzać tylko nieznaczną część prac innym przedsiębiorcom, przy założeniu, że reklamacje nabywców nieruchomości byłyby zgłaszane bezpośrednio inwestorowi. Jednocześnie wszystkie prace łącznie inwestora i jego kontrahentów wymienione w załączniku nr 14 (poz. 2-48) do ustawy o VAT składają się na jedną całość, tj. na wzniesienie obiektu zgodnie z projektem.

39 Zgodnie z art. 3 pkt 7 u.p.b. przez roboty budowlane należy rozumieć budowę, a także prace polegające na przebudowie, montażu, remoncie lub rozbiórce obiektu budowlanego. 
Analizowane zagadnienie można sprowadzić do zasadniczej kwestii, a mianowicie do tego, czy inwestor (deweloper) może być jednocześnie generalnym wykonawcą, traktowanym dualistycznie, tj. w taki sposób, że wymienione terminy nie będą używane zamiennie, a odpowiednio do funkcji, jaką inwestor pełni w realizacji inwestycji. Wyjaśnienie tego zagadnienia determinuje właściwe określenie statusu podwykonawcy, który to status wpływa na wybór odpowiedniego sposobu opodatkowania usług budowlanych, a w konsekwencji na prawidłowe rozliczenie podatku należnego bez faktycznego dokonywania jego transferu pomiędzy kontrahentami.

We wniosku z dnia 19 stycznia 2017 r. o wydanie interpretacji indywidualnej podatnik podniósł następującą argumentację odnoszącą się do możliwości zastosowania odwrotnego obciążania. Mianowicie wskazał, że ze względu na spoczywający na nim ustawowy obowiązek do ustanowienia prawa, o którym mowa w art. 1 ustawy z dnia 16 września 2011 r. o ochronie praw nabywcy lokalu mieszkalnego lub domu jednorodzinnego $^{40}$, oraz konieczności przeniesienia tego prawa na nabywcę nie może posiadać statusu ostatecznego konsumenta, w związku z czym nie będzie podatnikiem podatku od towarów i usług rozliczającym podatek na zasadach ogólnych. Istota takiego wnioskowania wyraża się w tym, że deweloper w wyniku odsprzedaży nieruchomości, stanowiącej efekt nabytych usług budowlanych na rzecz ostatecznych nabywców, jako inwestor nie stanie się konsumentem tych usług, ponieważ nie nabywa ich dla siebie. Tym samym zgodnie z wprowadzoną nowelizacją ustawy o VAT może być potraktowany jako główny wykonawca w stosunku do podwykonawcy, tym bardziej że byłoby to zgodne z intencją stron, wynikającą również $\mathrm{z}$ użytego w umowie o roboty budowlane nazewnictwa odnoszącego się do stron umowy.

Właściwa ocena zasadności przytoczonej argumentacji odnoszącej się do możliwości zastosowania mechanizmu odwrotnego obciążania uza-

40 Tekst jedn. Dz.U. z 2017 r. poz. 1468. Ustawa reguluje zasady ochrony praw nabywcy, wobec którego deweloper zobowiązuje się do ustanowienia odrębnej własności lokalu mieszkalnego i przeniesienia własności tego lokalu na nabywcę, albo do przeniesienia na nabywcę własności nieruchomości zabudowanej domem jednorodzinnym lub użytkowania wieczystego nieruchomości gruntowej i własności domu jednorodzinnego na niej posadowionego stanowiącego odrębną nieruchomość. 
leżniona jest od ustalenia celu umowy oraz zgodności tego celu z przepisami ustawowymi ${ }^{41}$. Ustalenie celu umowy jest możliwe poprzez dokonanie wykładni oświadczeń woli na podstawie przepisu w art. 65 § 1 i 2 k.c. ${ }^{42}$ Cel umowy to taki stan rzeczy, który ma być zrealizowany w następstwie wykonania uprawnień i obowiązków wynikających z dokonanej czynności prawnej. Należy przyjmować, że strony zawierające umowę działają racjonalnie, a więc przyjmują na siebie tylko takie zobowiązania, które są niezbędne do osiągnięcia ich celów, i dążą do uzyskania takich praw, które najpełniej pozwolą te cele zrealizować. Bez wątpienia przedmiotem umowy była realizacja usług wymienionych w załączniku nr 14 (poz. 2-48) do ustawy o VAT, a celem umowy na gruncie prawa cywilnego - wykonanie obowiązków określonych w art. 647 k.c.

W dalszej kolejności niezbędne staje się również ustalenie przyczyn umownego przyjęcia terminologii dotyczącej stron nieodpowiadającej pełnionym przez te strony rolom określonym w umowie o roboty budowlane. Przyjęte przez strony nazewnictwo skłania do wniosku, iż treść stosunku prawnego zaprzecza właściwości (naturze) umowy podwykonawczej, pozbawiając tę umowę jej istotnej cechy wyrażającej się w konieczności istnienia dwóch niezależnych podmiotowo stron stosunku prawnego, tj. wykonawcy i podwykonawcy, pełniących rolę wtórną wobec inwestora (dewelopera czy zamawiającego) ${ }^{43}$. Oznacza to, że konfiguracja,

41 Zasada swobody zawierania umów wyrażona w art. 353[1] k.c. i zasada poszanowania woli stron wyrażona w art. $65 \S 2$ k.c. są fundamentalnymi zasadami odzwierciedlającymi konstytucyjną gwarancję państwa prawa. Zakwestionowanie tych zasad może nastąpić jedynie na warunkach przewidzianych przepisami k.c., tj. w sytuacji stwierdzenia nieważności czynności prawnej, stwierdzenia wad oświadczenia woli, w tym pozorności umowy, bądź też stwierdzenia, że wynikający z umowy stosunek prawny co do treści lub celu sprzeciwia się właściwości stosunku, ustawie lub zasadom współżycia społecznego (zob. wyrok SA w Szczecinie z dnia 7 listopada 2017 r., III AUa 180/17, Lex nr 2463421).

42 Oświadczenie woli należy tłumaczyć tak, jak tego wymagają ze względu na okoliczności, w których zostało ono złożone, zasady współżycia społecznego oraz ustalone zwyczaje, a w umowach należy raczej badać, jaki był zgodny zamiar stron i cel umowy, aniżeli opierać się na jej dosłownym brzmieniu.

43 Zgodnie z zasadą swobody umów wyrażoną w przepisie art. 353[1] k.c. strony zawierające umowę mogą ułożyć stosunek prawny według swego uznania, byleby jego treść lub cel nie sprzeciwiały się właściwości (naturze) stosunku, ustawie ani zasadom współżycia społecznego. 
do której będzie miał zastosowanie mechanizm odwrotnego obciążenia, musi się składać z co najmniej trzech podmiotów, z których pierwszym będzie inwestor, następnym wykonawca, a kolejnym podwykonawca. Tego typu konstrukcji opartych na mechanizmie odwrotnego obciążenia może być więcej, w zależności od liczby fragmentów robót budowlanych powierzonych do wykonania przez inwestora innemu przedsiębiorcy lub przedsiębiorcom, przy czym opodatkowanie na zasadach ogólnych wystąpi wyłącznie pomiędzy inwestorem a wykonawcą.

Jednocześnie należy uznać, że przyjęcie w robotach budowlanych konstrukcji składającej się wyłącznie z dwóch podmiotów jako uzasadniającej zastosowanie mechanizmu odwróconego obciążenia jest niezgodne z intencją ustawodawcy, który przewidział ten sposób rozliczenia pomiędzy podwykonawcą a wykonawcą, a ogólny model opodatkowania pomiędzy wykonawcą a inwestorem. W przyjętej przez ustawodawcę konstrukcji, do której będzie miał zastosowanie mechanizm odwrotnego obciążenia, każde kolejne ogniwo, począwszy od (generalnego) wykonawcy, a skończywszy na ostatnim podwykonawcy, będzie opodatkowane na zasadzie odwróconego obciążenia ${ }^{44}$. W takiej konfiguracji podmiotowej do rozliczenia podatku jest zobowiązany nabywca usług, który otrzyma od podwykonawcy fakturę z kwotą netto, bez podatku od towarów i usług. Natomiast usługi realizowane przez generalnego wykonawcę bezpośrednio na rzecz inwestora (np. dewelopera budowlanego) podlegają opodatkowaniu według zasad ogólnych, tj. generalny wykonawca wystawia inwestorowi fakturę na kwotę należności za wykonane usługi zawierającą podatek od towarów i usług. W takim przypadku mechanizm odwróconego obciążenia nie ma zastosowania ${ }^{45}$.

Przedstawiona wykładnia omawianych przepisów koresponduje z orzecznictwem organów podatkowych, determinującym zastosowanie mechanizmu odwróconego obciążenia do usług realizowanych przez podwykonawcę na rzecz głównego wykonawcy, który to podwykonawca rozumiany jest jako dalszy wykonawca prac (częściowych lub całościowych) w ramach zleconej przez inwestora na rzecz głównego wykonawcy

44 Por. Objaśnienia podatkowe z 17 marca 2017 r. ... s. 6.

45 Tamże, s.7. 
inwestycji. Z przytoczonego stanowiska wynika zatem, że nie są usługami świadczonymi przez podwykonawców usługi świadczone bezpośrednio na rzecz inwestorów ${ }^{46}$.

Dokonana eksplikacja analizowanego uregulowania w najszerszym kontekście odpowiada celowi ustawodawcy, którym było uniemożliwienie, a przynajmniej pozbawienie sensu wystawiania faktur przez fikcyjnych podwykonawców, którzy albo w ogólne nie istnieli, albo nie świadczyli usługi na rzecz nabywcy, w sposób nieuprawniony dokonywali potrącenia podatku lub otrzymywali jego zwrot w przypadku zaistnienia nadwyżki podatku naliczonego nad należnym.

\section{Ocena efektywności rozwiązań prawnych wiązanych z poprawą ściągalności podatku od towarów i usług}

Wprowadzenie mechanizmu odwróconego obciążenia na usługi budowlane, jak wcześniej wspomniano, jest tylko jednym z kilku rozwiązań systemowych służących poprawie ściągalności podatku od towarów i usług, tzw. pakietu rozwiązań uszczelniających, do których zaliczyć należy w szczególności Jednolity Plik Kontrolny ${ }^{47}$, rozszerzenie odpowiedzialności solidarnej nabywcy za zaległości podatkowe ${ }^{48}$, a także zaostrzenie

46 Interpretacja indywidualna Dyrektora Krajowej Informacji Skarbowej z dnia 29.03.2017 r., 3063-ILPP1-2.4512.20.2017.2.JO, https://interpretacje-podatkowe.org/umowa/3063ilpp1-2-4512-20-2017-2-jo (dostęp: 20.12.2017 r.).

47 Na podstawie przepisu art. $82 \S 1$ b Ordynacji podatkowej (tekst jedn. Dz.U. z 2017 r., poz. 201) osoby prawne, jednostki organizacyjne niemające osobowości prawnej oraz osoby fizyczne, prowadzące księgi podatkowe przy użyciu programów komputerowych, są obowiązane, bez wezwania organu podatkowego, do przekazywania, za pomocą środków komunikacji elektronicznej, Szefowi Krajowej Administracji Skarbowej informacji o prowadzonej ewidencji, o której mowa w art. 109 ust. 3 ustawy o VAT, w postaci elektronicznej odpowiadającej strukturze logicznej, o której mowa w art. 193a § 2, na zasadach dotyczących przesyłania ksiąg podatkowych lub ich części określonych w przepisach wydanych na podstawie art. 193a § 3, za okresy miesięczne w terminie do 25. dnia miesiąca następującego po każdym kolejnym miesiącu, wskazując miesiąc, którego ta informacja dotyczy.

Na podstawie art. 96 ust 4b ustawy o VAT w przypadku zarejestrowania podatnika, którego zgłoszenie rejestracyjne zostało złożone przez pełnomocnika, pełnomocnik 
sankcji za udział w przestępstwach podatkowych związanych z wyłudzeniem podatku od towarów i usług ${ }^{49}$, mechanizm podzielonej płatności ${ }^{50}$ oraz ustawę STIR ${ }^{51}$.

Przed wprowadzeniem wymienionych powyżej rozwiązań poziom poboru podatków w Polsce, wyrażony jako procent PKB, był niższy niż w większych państwach członkowskich UE. Przykładowo w 2012 r. skuteczność poboru podatku od towarów i usług w Polsce była niższa niż w sąsiednich krajach, które przystąpiły do UE w tym samym okresie. Sytuacja związana z tym zjawiskiem stała się problematyczna z uwagi na fakt, iż podatek od towarów i usług jest największym podatkiem w Polsce.

odpowiada solidarnie wraz z zarejestrowanym podatnikiem do kwoty 500000 zł za zaległości podatkowe podatnika powstałe z tytułu czynności wykonanych w ciągu 6 miesięcy od dnia zarejestrowania podatnika jako podatnika VAT czynnego.

Przepis art. 112b ust. 2 ustawy o VAT przewiduje w przypadkach przewidzianych w ustawie dodatkowe zobowiązanie podatkowe w wysokości odpowiadającej 30\% kwoty zaniżenia zobowiązania podatkowego albo kwoty zawyżenia zwrotu różnicy podatku, zwrotu podatku naliczonego lub różnicy podatku do obniżenia podatku należnego za następne okresy rozliczeniowe. Przez zaostrzenie sankcji można również rozumieć inkryminowanie zachowania polegającego na poświadczeniu w fakturze VAT nieprawdy co do okoliczności faktycznych mogących mieć znaczenie dla określenia wysokości należności publicznoprawnej lub jej zwrotu albo zwrotu innej należności o charakterze podatkowym oraz używanie tego rodzaju dokumentu. Przestępstwo określone w art. 271a zostało dodane do ustawy Kodeks karny (tekst jedn. Dz.U. z 2018 r., poz. 1600) ustawą z dnia 10 lutego 2017 r. o zmianie ustawy - Kodeks karny oraz niektórych innych ustaw (Dz.U. z 2017 r., poz. 244), która weszła w życie z dniem 1 marca $2017 \mathrm{r}$.

50 Tzw. mechanizm split payment. Zmiana wprowadzona ustawą z dnia 15 grudnia 2017 r. o zmianie ustawy o podatku od towarów i usług oraz niektórych innych ustaw (Dz.U. z 2018 r., poz. 62) wprowadza w rozdziale 1a mechanizm podzielonej płatności. Zastosowanie tego mechanizmu polega na tym, że zapłata kwoty odpowiadającej całości albo części kwoty podatku wynikającej z otrzymanej faktury jest dokonywana na rachunek VAT, a zapłata całości albo części kwoty odpowiadającej wartości sprzedaży netto wynikającej z otrzymanej faktury jest dokonywana na rachunek bankowy albo na rachunek w spółdzielczej kasie oszczędnościowo-kredytowej, dla których jest prowadzony rachunek VAT, albo jest rozliczana w inny sposób.

51 Ustawa z dnia 24 listopada 2017 r. o zmianie niektórych ustaw w celu przeciwdziałania wykorzystywaniu sektora finansowego do wyłudzeń skarbowych (Dz.U. z 2017 r., poz. 2491). STIR - rozumie się przez to system teleinformatyczny izby rozliczeniowej spełniający minimalne wymagania dla systemów teleinformatycznych określone w przepisach wydanych na podstawie art. 18 ustawy z dnia 17 lutego 2005 r. o informatyzacji działalności podmiotów realizujących zadania publiczne (tekst jedn. Dz.U. z 2017 r., poz. 570). 
Przyczynić się mogło do tego rozdrobnienie administracji skarbowej, która została zreformowana ustawą z dnia 16 listopada 2016 r. o Krajowej Administracji Skarbowej ${ }^{52}$.

Zaprezentowane powyżej rozwiązania, będące częścią reformy systemu podatkowego, ukierunkowane zostały na poprawę ściągalności podatków, a tym samym na zwiększenie wpływów do budżetu z tego tytułu. Jeżeli chodzi o długofalowy skutek wprowadzonych zmian, to upłynął zbyt krótki okres, żeby to ocenić a posteriori. Oczywiście planując wpływy budżetowe, można, a nawet powinno się prognozować wzrost wpływów z podatków, w szczególności podatku od towarów i usług. Z założeń budżetowych wynika, że w 2018 r. stawki podatku od towarów i usług pozostaną na poziomach obowiązujących w 2017 r. Jednocześnie w 2018 r. spodziewane są wpływy z zawieszonego obecnie podatku od sprzedaży detalicznej ${ }^{53}$. Na poprawę poziomu dochodów budżetu państwa w 2018 r. istotny wpływ mają mieć także działania związane z poprawą przestrzegania przepisów podatkowych ograniczających istnienie tzw. luki podatkowej w podatku od towarów i usług, stanowiące główny cel Krajowej Administracji Skarbowej ${ }^{54}$.

Z danych Ministerstwa Finansów wynika, że w I kwartale 2017 r. dochody sektora instytucji rządowych i samorządowych (wg zasad ESA 2010) wyniosły 186,7 mld zł (tj. 41,1\% PKB) i były wyższe od wykonania dochodów w analogicznym okresie roku poprzedniego aż o 8,7\% r/ $\mathrm{r}^{55}$, co wynikało przede wszystkim ze wzrostu dochodów z podatków o 13,7\% r/r. Na uwagę zasługuje fakt, że największy udział we wzroście dochodów podatkowych miały dochody z tytułu podatku od towarów i usług (7,7\% PKB), które (wg zasad ESA 2010) w I kwartale 2017 r. były o 39,2\% wyższe niż w analogicznym okresie 2016 r., co wynikało w części z efektu niskiej bazy statystycznej (dochody z tytułu podatku od towarów

\footnotetext{
Dz.U. z 2016 r. poz. 1947.

53 Ustawa z dnia 6 lipca 2016 r. o podatku od sprzedaży detalicznej (tekst jedn. Dz.U. z 2017 r., poz. 1918).

54 Założenia do projektu budżetu państwa na rok 2018, 6 czerwca 2017, https://www.mf.gov.pl/ministerstwo-finansow/wiadomosci/komunikaty-/asset_publisher/ 6Wwm/content/id/6029692 (dostęp: 06.06.2017 r.).

55 W ujęciu rocznym.
} 
i usług w I kwartale 2016 r. ukształtowały się na rekordowo niskim poziomie 5,5\% PKB, przy średniej z ostatnich 15 lat na poziomie 7\% PKB). Istotną rolę we wzroście wpływów z podatku od towarów i usług odegrały czynniki makroekonomiczne, tj. wzrost nominalnej sprzedaży detalicznej oraz nominalnej produkcji sprzedanej, jak też widoczne były efekty zmian w przepisach podatkowych uszczelniających system poboru podatku od towarów i usług ${ }^{56}$.

W II kwartale 2017 r. dochody sektora instytucji rządowych i samorządowych (wg zasad ESA 2010) wyniosły 188,1 mld zł (tj. 39,7\% PKB) i były wyższe od wykonania dochodów w analogicznym okresie roku poprzedniego o 7,5\% r/r, co wynikało przede wszystkim ze wzrostu dochodów z podatków o 10,3\% r/r. Największy udział we wzroście dochodów podatkowych miały dochody z tytułu podatku od towarów i usług (8,0\% PKB), które (wg zasad ESA 2010) w II kwartale 2017 r. były o 12,8\% wyższe niż w analogicznym okresie 2016 r. $^{57}$

W III kwartale 2017 r. dochody sektora instytucji rządowych i samorządowych (wg zasad ESA 2010) wyniosły 198,2 mld zł (tj. 40,7\% PKB) i były nominalnie wyższe od dochodów w analogicznym okresie 2016 r. o 9,0\% r/r (wzrost relacji o 0,7 p.p. PKB). Największy udział we wzroście miały dochody podatkowe, które były wyższe o 9,0\% r/r. Największy udział we wzroście dochodów podatkowych miały dochody z tytułu podatku od towarów i usług, które (wg zasad ESA 2010) w III kwartale 2017 r. były wyższe niż w analogicznym okresie 2016 r. o 15,5\% r/r, podczas gdy główny element bazy podatku od towarów i usług, tj. spożycie prywatne, w tym okresie wzrosło nominalnie o 6,6\% r/r. Satysfakcjonujący wpływ podatku od towarów i usług został zdeterminowany poprzez zarówno czynniki makroekonomiczne, jak i efekty działań uszczelniają-

56 Ministerstwo Finansów, Informacja kwartalna o stanie finansów publicznych w I kwartale 2017 r., 2017, nr 3, s. 4,

http://www.finanse.mf.gov.pl/documents/764034/1002163/Informacja+kwartalna+I+k w.+2017+r. (dostęp: 02.11.2017 r.).

57 Ministerstwo Finansów, Informacja kwartalna o stanie finansów publicznych w II kwartale 2017 r., 2017, nr 4, s. 4-5, https://www.mf.gov.pl/documents/764034/1002163/Informacja+kwartalna+II+kw.+20 17+r. (dostęp: 02.11.2017 r.). 
cych system poboru podatku od towarów i usług. Z informacji Ministerstwa Finansów wynika, że w porównaniu do krajów europejskich Polska odnotowała najwyższy wzrost dochodów sektora $\mathrm{GG}^{58} \mathrm{z}$ podatku od towarów i usług do PKB w okresie trzech pierwszych kwartałów 2017 r. (o 1 pkt proc. r/r; w UE wzrost wyniósł 0,1 pkt proc. r/r) ${ }^{59}$.

W IV kwartale 2017 r. dochody sektora instytucji rządowych i samorządowych z CIT, wg zasad ESA 2010, wyniosły w 2017 r. 38,5 mld zł i były wyższe o 12,3\% w stosunku do poprzedniego roku. Do wzrostu dochodów podatkowych z CIT przyczyniły się m.in. działania uszczelniające system podatkowy, w tym przepisy normujące klauzulę przeciwko unikaniu opodatkowania, które pozwoliły na zwalczanie czynności wykorzystywanych do unikania zapłaty podatku. W całym 2017 r. poza wzrostem dochodów podatkowych do poprawy wyniku sektora instytucji rządowych i samorządowych przyczynił się wzrost - o ok. 0,2 pkt proc. PKB (nominalnie o ok. 7,9\% r/r) - dochodów sektora z tytułu składek na ubezpieczenia społeczne rejestrowanych w podsektorze ubezpieczeń społecznych. Wzrost ten był głównie rezultatem dobrej sytuacji na rynku pracy (silny wzrost zatrudnienia połączony ze wzrostem wynagrodzeń) ${ }^{60}$.

W I kwartale 2018 r. dochody sektora instytucji rządowych i samorządowych (wg zasad ESA 2010) wyniosły 206,0 mld zł i były wyższe od wykonania dochodów $\mathrm{w}$ analogicznym okresie roku poprzedniego o 11,3\% (r/r) (wzrost relacji o 1,9 pkt proc. PKB). Nominalny wzrost wpływów z podatków (wg zasad ESA 2010), które mają największy udział w dochodach, wyniósł 13,9\% (r/r). Dochody z tytułu podatku VAT (wg zasad ESA 2010) w I kwartale 2018 r. były nominalnie wyższe aż o 19,5\% niż w analogicznym okresie 2017 r. W I kwartale realny wzrost sprzedaży detalicznej wyniósł $8,1 \% \mathrm{r} / \mathrm{r}$, a nominalnej produkcji

\footnotetext{
Ang. general government.

59 Ministerstwo Finansów, Informacja kwartalna o stanie finansów publicznych w III kwartale 2017 r., 2018, nr 1, s. 4,

https://www.mf.gov.pl/documents/764034/1002163/Informacja+kwartalna+III+kw.+2 017+r. (dostęp: 31.01 .2018 r.).

60 Ministerstwo Finansów, Informacja kwartalna o stanie finansów publicznych w IV kwartale 2017 r. i całym 2017 r., 2018, nr 2, s. 4-5, https://www.mf.gov.pl/documents/764034/1002163/Informacja+kwartalna+IV+kw.+2 017+r. (dostęp: 30.05.2018 r.).
} 
sprzedanej 5,7\% r/r. Pozytywnie na dochody z VAT wpłynął niski przyrost zwrotów podatku, który był wyższy niż przed rokiem o 3,4\% r/ $\mathrm{r}^{61}$.

Istotne informacje wynikają również z kolejnych danych Ministerstwa Finansów, które podaje, że główną przyczyną wzrostu dochodu z tytułu podatku od towarów i usług było uszczelnienie systemu podatkowego, które skutkowało zmniejszeniem zadeklarowanych kwot zwrotów o 4,19 mld zł oraz zwiększeniem o ok. 9,73 mld zł wpływów z tytułu tego podatku. Znamienny jest również fakt, że w latach 2016-2017 nominowane dochody z tytułu podatku od towarów i usług zmieniły się o 26,88 mld (w porównaniu z 2015 r. przy założeniu dochodów na poziomie 150 mld zł) ${ }^{62}$. Natomiast na podstawie dostępnych danych nie jest możliwe wskazanie stopnia przyczynienia się do poprawy ściągalności podatków konkretnego z wprowadzonych rozwiązań prawnych.

\section{Podsumowanie}

Z przytoczonych danych statystycznych Ministerstwa Finansów wynika, że ściągalność podatków, w szczególności podatku od towarów i usług, wzrosła również dzięki wprowadzonym zmianom legislacyjnym, które w tym momencie należy ocenić pozytywnie. Wzrost ściągalności podatków jest jednym pozytywnym aspektem reformy, zwrócić należy także uwagę, że wzrost ściągalności podatków w wyniku uszczelnienia systemu podatkowego może zaowocować planowanym obniżeniem stawki podatku od towarów i usług, a także skróceniem terminu zwrotu tego podatku ${ }^{63}$.

Z pewnością do osiągnięcia celu ustawodawcy przysłuży się zarówno wprowadzone $\mathrm{w}$ ostatnim czasie uregulowanie $\mathrm{w}$ zakresie penalizacji czynów związanych z wystawianiem tzw. pustych faktur, jak i wprowa-

61 Ministerstwo Finansów, Informacja kwartalna o stanie finansów publicznych w I kwartale 2018 r., 2018, nr 3,

https://www.mf.gov.pl/documents/764034/1002163/Informacja+kwartalna+I+kw.+201 8+r. (dostęp: 30.07.2018 r.).

62 Ministerstwo Finansów, Dochody i zwroty w VAT w latach 2007-2017, 9.08.2017, https://www.mf.gov.pl/ministerstwo-finansow/dla-mediow/informacje-prasowe//asset_publisher/6PxF/content/id/6088684 (dostęp: 09.08.2017 r.).

Zmiana brzmienia art. 87 ust. 2 ustawy o VAT. 
dzony mechanizm split payment. Przeciwdziałanie zjawisku wyłudzenia podatku od towarów i usług przy użyciu instrumentów prawnokarnych należy uznać za metodę komplementarną i niezbędną w stosunku do reformy ustaw podatkowych. Zaznaczyć należy, iż inkryminowanie przestępczości polegającej na tworzeniu nieprawdziwych, nierzetelnych dokumentów, które dotyczą okoliczności faktycznych mogących mieć znaczenie dla określenia należności publicznoprawnej ${ }^{64}$, ma nie tylko służyć przeciwdziałaniu zjawisku wyłudzeń podatku od towarów i usług o bardzo rozległej dla finansów państwa skali poprzez penalizację przestępstw przeciwko dokumentom (wiarygodności faktur), ale również przeciwdziałaniu zjawiskom w istotny sposób zaburzającym konkurencję i zasady wolnego rynku ${ }^{65}$.

Należy również poczynić kilka uwag odnoszących się do funkcji mechanizmu odwróconego obciążenia w kontekście badanego modelu. Analiza omawianej konstrukcji prowadzi do wniosku, że skuteczność wprowadzanych reform jest przede wszystkim uzależniona od sposobu interpretacji przepisów, mającej na celu eliminację z obrotu konstrukcji sztucznych (oderwanych od istoty rzeczy, do których się odnoszą), tworzonych w celu obejścia przepisów ustawy podatkowej. Zaprezentowane w analizowanej interpretacji podatkowej niewłaściwe rozumienie przez podatnika funkcji mechanizmu odwróconego obciążenia wykluczyłoby możliwość realizacji celu założonego przez ustawodawcę zarówno krajowego, jak i unijnego, którym w przypadku wprowadzenia mechanizmu odwrotnego obciążenia jest wyeliminowanie faktycznego przepływu podatku pomiędzy kontrahentami, a w konsekwencji zapobieżenie nieuzasadnionemu zwrotowi.

\section{Bibliografia:}

Borszowski P., Klauzula przeciwko unikaniu opodatkowania. Praktyczne vademecum podatnika - 2017, Oficyna Wydawnicza „Unimex”, Wrocław 2017.

Brzeziński. B., Szkice z wykładni prawa podatkowego, ODDK, Gdańsk 2002.

64 Założeniem jest penalizacja przestępstw przeciwko dokumentom (wiarygodności faktur).

65 Projekt ustawy o zmianie ustawy - Kodeks karny..., s. 9-10. 
Dominik-Ogińska D., Polakowski D., Mechanizm odwróconego obciq̨żenia podatkiem od towarów i usług na usługi budowlane. Praktyczne vademecum podatnika, Oficyna Wydawnicza „Unimex”, Wrocław 2017.

Duży J., Zorganizowana przestępczość podatkowa w Polsce. Zwalczanie przestępnego nadużycia mechanizmów podatków VAT i akcyzowego, Lex a Wolters Kluwer business, Warszawa 2013.

Fornalik J. tyt. XI, art. 193-212 [w:] K. Sachs, R. Namysłowski (red.), Dyrektywa VAT, Lex a Wolters Kluwer business, Warszawa 2008.

Majczyna M., Odwrotne obciq̨żenie a oszustwa w VAT, [w:] I. Ożóg (red.), Przestępstwa karuzelowe i inne oszustwa w VAT, Wolters Kluwer Polska, Warszawa 2017.

Plucińska-Filipowicz A., Wierzbowski M. (red.), Prawo budowlane, Wydawnictwo Wolters Kluwer, Warszawa 2016.

Szlęzak-Matusewicz J., Odwrotne obciq̨żenie podatkiem od towarów i usług jako mechanizm przeciwdziałajacy oszustwom podatkowym, „Zeszyty Naukowe Uniwersytetu Szczecińskiego nr 864, Finanse, Rynki Finansowe, Ubezpieczenia” 2015, nr 76, t. 1, http://www.wneiz.pl/nauka_wneiz/frfu/762015/FRFU-76-t1-265.pdf (dostęp: 17.09.2018 r.).

Wojda M., tyt. XI, art. 200, [w:] J. Martini (red.), Dyrektywa VAT 2006/112/WE, Oficyna Wydawnicza „Unimex”, Wrocław 2010. 